\title{
Glucagon-like peptide-1 analogs against antipsychotic-induced weight gain: potential physiological benefits
}

\author{
Bjørn H Ebdrup ${ }^{1 *}$, Filip K Knop ${ }^{2}$, Pelle L Ishøy ${ }^{1}$, Egill Rostrup ${ }^{3}$, Birgitte Fagerlund ${ }^{1}$, Henrik Lublin ${ }^{1}$ and \\ Birte Glenthøj ${ }^{1}$
}

\begin{abstract}
Background: Antipsychotic-induced weight gain constitutes a major unresolved clinical problem which may ultimately be associated with reducing life expectancy by 25 years. Overweight is associated with brain deterioration, cognitive decline and poor quality of life, factors which are already compromised in normal weight patients with schizophrenia.

Here we outline the current strategies against antipsychotic-induced weight gain, and we describe peripheral and cerebral effects of the gut hormone glucagon-like peptide-1 (GLP-1). Moreover, we account for similarities in brain changes between schizophrenia and overweight patients.

Discussion: Current interventions against antipsychotic-induced weight gain do not facilitate a substantial and lasting weight loss. GLP-1 analogs used in the treatment of type 2 diabetes are associated with significant and sustained weight loss in overweight patients. Potential effects of treating schizophrenia patients with antipsychotic-induced weight gain with GLP-1 analogs are discussed.

Conclusions: We propose that adjunctive treatment with GLP-1 analogs may constitute a new avenue to treat and prevent metabolic and cerebral deficiencies in schizophrenia patients with antipsychotic-induced weight gain. Clinical research to support this idea is highly warranted.
\end{abstract}

\footnotetext{
* Correspondence: bebdrup@cnsr.dk

${ }^{1}$ Center for Neuropsychiatric Schizophrenia Research, CNSR and Center for Clinical Intervention and Neuropsychiatric Schizophrenia Research, CINS, Psychiatric Center Glostrup, University of Copenhagen, DK-2600 Glostrup, Denmark

Full list of author information is available at the end of the article
}

Keywords: Schizophrenia, antipsychotic medication, overweight, diabetes, GLP-1, exenatide, liraglutide, neuroprotection, cognition

\section{Background}

Schizophrenia is a severe and heterogeneous brain disease with a prevalence of approximately $0.5 \%$ in the world population [1]. Antipsychotics constitute the cornerstone in the treatment of schizophrenia. At the same time, much of the excess mortality in patients with schizophrenia may be attributed to metabolic side effects induced by antipsychotics [2]. The prevalence of overweight (body mass index (BMI) $\geq 25 \mathrm{~kg} / \mathrm{m}^{2}$ ) and obesity (BMI $\geq 30 \mathrm{~kg} / \mathrm{m}^{2}$ ) has been estimated at approximately $60 \%$ among schizophrenia patients [3] compared to less than 20 to $30 \%$ in the general population [4-7]. Accordingly, patients with schizophrenia may lose 25 or more years of life expectancy, with the majority of this excess in premature deaths being attributed to obesity-related cardiovascular disease and not to suicide $[2,8]$.

Both genetic and environmental factors are contributing to this pronounced co-morbidity between schizophrenia and overweight $[9,10]$. Among the latter, antipsychotic drugs and, especially, second generation antipsychotics (SGAs) play a pivotal role [11,12]. Particularly, clozapine and olanzapine are associated with excessive weight gain (up to $2 \mathrm{~kg}$ per month) [13,14], but also the metabolism of glucose and lipids is affected to a varying degree $[15,16]$. Non-alcoholic fatty liver disease (NAFLD), which is a commonly known complication to obesity, may also be a possible side effect of antipsychotic drug treatment, and a high prevalence of NAFLD has been observed in schizophrenia patients [16]. Thus, in the present-day clinical setting optimal antipsychotic treatment is often compromised due to antipsychotic-induced weight gain and 'dysmetabolism'.

\section{() Biomed Central}


Obesity is considered the single most important risk factor for development of dyslipidaemia, diabetes, cardiovascular disease and ultimately premature death [17]. Also, obesity is associated with stigmatization and compromised quality of life $[18,19]$. According to the World Health Organization, schizophrenia is one of the seven most disabling diseases as measured in 'years lived with disability' among 15 to 44 year-olds, while diabetes is number 20 [20]. Co-morbidity between schizophrenia and obesity is likely to further impair quality of life and shorten the life span. Moreover, medical costs for obese individuals (without psychiatric co-morbidity) are 30\% higher than those of normal weight individuals [21]. Accordingly, initiatives to promote a healthier weight will also have health economic benefits [22].

The following section begins by outlining current strategies against antipsychotic-induced weight gain, and by describing both peripheral and cerebral effects of the gut hormone glucagon-like peptide-1 (GLP-1). Next, we account for similarities in brain changes between schizophrenia [23] and overweight patients [24]. Finally, we propose that adjunctive treatment with a GLP-1 analog holds promise as a novel method to treat metabolic and cerebral deficiencies in schizophrenia patients with antipsychoticinduced weight gain.

\section{Discussion}

\section{Current interventions against antipsychotic-induced weight gain}

Current interventions against antipsychotic-induced weight gain fall into three categories. The first category involves changing antipsychotic medication to a compound less prone to result in weight gain. This strategy is recommended in clinical guidelines and results in a modest slowing of antipsychotic-induced weight gain to approximately $1.9 \mathrm{~kg}$ [11]. Change of medication, however, may increase the risk of exacerbating psychotic symptoms [11]. The second category involves lifestyle intervention and/or cognitive therapy and appears to slowdown the SGA-induced weight gain by $2.6 \mathrm{~kg}$ after 3 to 4 months; $4.2 \mathrm{~kg}$ after 6 months; and $3.1 \mathrm{~kg}$ after 12 to 18 months of treatment [25]. Finally, adjuvant medical treatment, the third category, has been attempted with numerous drugs, including ephedrine, sibutramine, orlistat, nizatidine, cimetidine, naltrexone, amantadine, reboxetine, fluoxetine, topiramate, dextroamphetamine, $\mathrm{d}$-fenfluramine, famotidine, fluvoxamine, phenylpropanolamine, rosiglitazone, metformin and the combination of metformin and sibutramine [26]. Metformin is by far the most investigated of these drugs and is associated with the most pronounced deceleration of antipsychotic-induced weight gain: $2.9 \mathrm{~kg}$ over 13 weeks compared with placebo [26]. Metformin, however, is considered a weight neutral intervention in the treatment of type 2 diabetes [27].
Notably, all current interventions are weight neutral at best. This is the case because a weight reducing intervention may mask a net weight gain (for example, a reported weight loss of $4 \mathrm{~kg}$ may be based on a $2 \mathrm{~kg}$ weight gain in the intervention group compared with a $6 \mathrm{~kg}$ weight gain in the placebo group [28]). Absolute, placebo-controlled weight loss has only been achieved by means of resourcedemanding interventions comprising strict diets and intensive physical training among hospitalized patients [29] or during short treatment periods ( $\leq 12$ weeks) [30].

In the general population, treatment of obesity often comprises a combination of diet, exercise, modification of daily routines and medication [31]. Currently, orlistat (a lipase inhibitor), sibutramine (a serotonin-norepinephrine reuptake inhibitor) and sympathomimetics are the only approved drugs with the indication obesity [32]. Bariatric surgery (for example, gastric bypass surgery) is the single most efficient way to achieve lasting weight loss. However, this intervention is not without risk and, therefore, only indicated in selected patients (for example, morbid obesity $\left(\mathrm{BMI} \geq 40 \mathrm{~kg} / \mathrm{m}^{2}\right)$ ) [33].

Thus, there is an exigent need for better treatment strategies as well as a deeper understanding of the physiological consequences of the weight gain and the metabolic side effects associated with antipsychotic drugs. One such strategy may involve the effects of currently available GLP-1 analogs.

\section{GLP-1 physiology and GLP-1 based treatment}

GLP-1 is a gut peptide hormone synthesized in endocrine $\mathrm{L}$ cells in the intestinal mucosa. GLP-1 is secreted into circulation after food intake. In the pancreas, GLP-1 stimulates glucose-induced insulin secretion (an incretin hormone) and inhibits glucagon secretion, thereby substantially contributing to maintaining the glucose homeostasis [34]. Activation of both peripheral GLP-1 receptors and GLP-1 receptors in the central nervous system reduces appetite and food intake thereby ensuring that body weight is kept down. In accordance with these observations, GLP-1 analogs for the treatment of type 2 diabetes have been developed (generally lowering HbA1c approximately $1 \%)$. A recent meta-analysis of studies of obese patients (with and without type 2 diabetes) demonstrated that $\geq 20$ weeks of treatment with a GLP-1 analog (compared to other antidiabetic drugs, including metformin) induced a weight loss of $3 \mathrm{~kg}$ [35]. Since previous antidiabetic treatment strategies are generally associated with weight gain, the weight reducing effect of GLP-1 analogs may be of vital importance in the treatment of type 2 diabetes.

Clinically, the degree of weight loss appears to be positively correlated with the dose of GLP-1 analog. A recent two-year prospective study (including non-diabetic patients with baseline $\mathrm{BMI} \geq 30$ randomized to treatment 
with the GLP-1 analog liraglutide (2.4 to $3.0 \mathrm{mg}$ oncedaily) or placebo) reported a weight loss of $7.8 \mathrm{~kg}$ (compared to a $2 \mathrm{~kg}$ weight loss in the placebo group) [36]. Moreover, preclinical studies have indicated that GLP-1 analog treatment can reduce lipid accumulation in the liver $[37,38]$.

Interestingly, a preclinical study has shown that olanzapine-induced weight gain and metabolic derangements in rats are reversed after treatment with the GLP-1 analog liraglutide [39].

\section{GLP-1 analogs}

At present, six different GLP-1 analogs have been subject to trials: exenatide (Eli Lilly), liraglutide (Novo Nordisk), albiglutide (GlaxoSmithKline), taspoglutide (Ipsen and Roche), lixisenatide (Sanofi-Aventis) and LY2189265 (Eli Lilly). Only exenatide and liraglutide have been approved by the U.S. Food and the Drug Administration and European Medicines Agency. GLP-1 analogs have the indication type 2 diabetes in combination with metformin and/or sulphonylurea, when treatment with these drugs is insufficient. Much academic and commercial effort is being put into investigating the possibility of extending the indication to obesity. Both exenatide and liraglutide are administered subcutaneously. Exenatide exists in two formulations: twice daily $\left(\right.$ Byetta $\left.^{\circledR}\right)$ and once weekly (Bydureon ${ }^{\circledR}$, Eli Lilly and Company, Indianapolis, Indiana, USA). Liraglutide (Victoza ${ }^{\circledR}$, Novo Nordisk A/S, Bagsvaerd, Denmark) is administered once daily.

The major side effects of exenatide and liraglutide are mild to moderate nausea and vomiting. These side effects are dose-dependent and decline over time and they do not explain the observed weight loss associated with GLP-1 analog treatment [40]. The incidence of treatment-associated hypoglycemia is low (European Medicines Agency).

\section{Cerebral effects of GLP-1}

Besides the effects of GLP-1 analogs on hyperglycemia and obesity (and possibly on hepatic lipid deposition), activation of central GLP-1 receptors may stimulate neural plasticity and prevent apoptosis, thereby suggesting involvement of GLP-1 in neuroprotection and learning [41,42]. An animal model of Alzheimer's disease has been used to show that the GLP-1 analog liraglutide prevents memory impairment and increases both neurogenesis as well as synaptic plasticity in the hippocampus $[43,44]$. In models of Parkinson's disease [45] and Huntington's chorea [46], dopaminergic neurons were protected and motor deficits improved when exposed to the GLP-1 analog exenatide.

Structural brain changes in schizophrenia and overweight It is well-established that schizophrenia is characterized by structural brain changes [47]. Already at first presentation of symptoms, reductions in total brain volume and hippocampus volume, along with increased ventricle volume, can be observed $[48,49]$. Moreover, the volumes of the dopamine-sensitive striatal regions appear to be reduced before initiation of antipsychotic treatment [50]. Progressive cerebral volume loss, for example, enlarged ventricles, is associated with more negative symptoms, cognitive decline and a more severe course of illness [23]. Current antipsychotic drugs have a limited effect on these symptom dimensions, and interventions with convincing neurotrophic properties are still lacking in the treatment of schizophrenia [51].

Growing evidence suggests that overweight is also associated with structural brain changes and cognitive deficits [24]. Large cross-sectional structural magnetic resonance imaging studies of obese patients have shown both global gray matter volume reductions (independently of age) [52] and widespread regional structural abnormalities in areas implicated in cognitive functions, impulse control and reward processing (for example, prefrontal cortex and striatum) $[53,54]$. These observations are supported by magnetic resonance spectroscopy and single-photon emission computed tomography studies suggesting that elevated BMI is associated with both neuronal abnormalities in frontal brain regions $[55,56]$ and impaired cognitive function [57]. In schizophrenia, reduced prefrontal blood perfusion also appears to be associated with more negative symptoms [58]. Besides similarities in gray matter changes in schizophrenia and obesity, also coinciding white matter abnormalities in corpus callosum and fronto-temporal tracts have been reported $[59,60]$.

Although brain abnormalities associated with obesity are already present in adolescents [61], it is still unclear if structural brain abnormalities precede the disorder as is the case in schizophrenia [62]. To our knowledge, weight loss has not been associated with changes in brain volume. In the available study addressing this issue, only global brain volume was assessed [63], thereby rendering the possibility that weight loss may still have a regional effect on brain volume. Nevertheless, some of the cognitive deficits associated with elevated BMI (that is, memory and attention/executive functioning) may be reversed after intentional weight loss [64].

\section{Functional brain changes in schizophrenia and overweight}

Functional neuroimaging studies have further established the indications of a shared substrate for schizophrenia and obesity. For example, satiety appears to be controlled by the prefrontal cortex, which sends inhibitory inputs to the limbic and paralimbic regions, thereby suppressing hunger [65]. Studies using positron emission tomography have compared obese, previously obese and lean subjects and found abnormal cerebral blood flow in the insula 
and hippocampus in both obese and previously obese, but not in lean subjects [65]. This suggests that in obesity, disturbances in the satiety network are 'trait' rather than 'state' dependent. Interestingly, abnormal hippocampal-prefrontal connectivity appears to be present in first-episode schizophrenia, but also in subjects at high risk for developing schizophrenia [66].

More recently it has also been suggested that the regional disturbances in the responsivity of the reward system (for example, in the ventral striatum) may explain excessive food intake, thereby increasing the risk of developing overweight [67]. Of note, reward disturbances are also becoming increasingly recognized in schizophrenia patients as they even appear to precede the initiation of antipsychotic treatment [68].

\section{Potential clinical implications of GLP-1 analog treatment} First, encouraging and growing evidence supports that a sizable and enduring weight loss can be obtained by GLP1 analog treatment in both diabetic and non-diabetic overweight or obese patients. Concurrently, an improved glycemic control is obtained. Second, a striking overlap appears to exist between key pathophysiological findings in schizophrenia and overweight/obesity. The extent to which this overlap is driven by the weight gain induced by antipsychotic medication or is caused by interactions from shared pathophysiological mechanisms warrants clarification. A shared substrate between schizophrenia and overweight will likely involve shared genetic risk factors [13]. With changes in body weight, physiological mechanisms may also come into play $[64,69]$. As such, exploration of the cerebral effects of GLP-1 analogs in overweight/obese subjects as well as in schizophrenia patients with antipsychotic induced weight gain will help to elucidate this proposed overlap between the two disorders.

An apparent way forward is initiation of clinical studies addressing whether GLP-1 analog treatment can reduce body weight in patients with antipsychotic-induced weight gain. In fact, there is currently a study investigating whether the GLP-1 analog exenatide can induce weight loss in obese patients treated with olanzapine [70]. Since previously un-medicated schizophrenia patients are in particularly high risk of developing metabolic side effects [71], addressing whether or not GLP-1 analog treatment can prevent weight gain is also pertinent. Finally, the indications of the procognitive and neurotrophic effects of GLP1 call for further investigation. If the progressive brain loss and cognitive decline associated with schizophrenia and overweight/obesity can indeed be ameliorated by GLP-1 treatment, this will have major implications for future treatment of schizophrenia, but also for the treatment of obesity. In psychiatry, particular priority should be given

Table 1 Effects of GLP-1 analogs with relevance for schizophrenia

\begin{tabular}{|c|c|c|c|}
\hline $\begin{array}{l}\text { Unresolved } \\
\text { challenges in } \\
\text { schizophrenia }\end{array}$ & Effect of GLP-1 analog treatment & Current level of evidence & Reference(s) \\
\hline \multicolumn{4}{|l|}{$\begin{array}{l}\text { Endocrinological } \\
\text { issues }\end{array}$} \\
\hline $\begin{array}{l}\text { Weight gain (non- } \\
\text { diabetes) }\end{array}$ & $\begin{array}{l}\text { Weight loss } \\
\text { Improved glycaemic control (1\% reduction in HbA1c) } \\
\text { Reduction in plasma levels of cholesterol and liver enzymes } \\
\text { Improved beta cell function } \\
\text { Reduction in systolic and diastolic blood pressure }\end{array}$ & $\begin{array}{l}\text { Prospective } \mathrm{RCT}^{*} \text { ( } 2 \text { years) } \\
\text { and systematic review with } \\
\text { meta-analyses of RCTs* }\end{array}$ & {$[35,36]$} \\
\hline $\begin{array}{l}\text { Diabetes } \\
\text { (dysmetabolism) }\end{array}$ & $\begin{array}{l}\text { Weight loss } \\
\text { Improved glycaemic control (1\% reduction in } \mathrm{HbA} 1 \mathrm{c}) \\
\text { Reduction in plasma levels of cholesterol and liver enzymes } \\
\text { Improved beta cell function } \\
\text { Reduction in systolic and diastolic blood pressure }\end{array}$ & $\begin{array}{l}\text { Cochrane systematic review } \\
\text { and systematic review with } \\
\text { meta-analyses of RCTs* }\end{array}$ & {$[35,72]$} \\
\hline $\begin{array}{l}\text { Non-alcoholic fatty } \\
\text { liver disease }\end{array}$ & Reduction of hepatic lipid deposition & Preclinical studies & {$[37,38]$} \\
\hline \multicolumn{4}{|l|}{$\begin{array}{l}\text { Neuropsychiatric } \\
\text { issues }\end{array}$} \\
\hline Cognition & Improvement of memory deficits & Preclinical studies & {$[41,43]$} \\
\hline $\begin{array}{l}\text { Extrapyramidal side } \\
\text { effects }\end{array}$ & Reduction of dyskinesia and regeneration of dopaminergic neurons & Preclinical studies & {$[45,46]$} \\
\hline Neuroprotection & $\begin{array}{l}\text { Increased neurogenesis and modulation of synaptic plasticity in the } \\
\text { hippocampus }\end{array}$ & Preclinical studies & {$[43,44]$} \\
\hline Quality of life & $\begin{array}{l}\text { Improved well-being and reduced Hospital Anxiety and Depression Scale } \\
\text { after six months compared to diabetic patients treated with insulin (the } \\
\text { improvement was found to be independent of changes in body mass } \\
\text { index) }\end{array}$ & $\begin{array}{l}\text { Prospective, observational } \\
\text { study }\end{array}$ & {$[73]$} \\
\hline
\end{tabular}


to the effects of early adjunctive GLP-1 treatment, that is, in first-episode schizophrenia patients.

Current data certainly bear the connotation of adjunctive treatment with GLP-1 analog as a potential 'magic bullet' for addressing hitherto unresolved challenges in schizophrenia. Table 1 summarizes the hypothetical implications of GLP-1 treatment in antipsychotic-induced weight gain.

\section{Conclusions}

Psychiatry is facing a major unmet need for addressing the severe metabolic side effects induced by antipsychotics. While awaiting the development of antipsychotic drugs with fewer side effects and more convincing neuroprotective and procognitive properties, an optimized treatment of schizophrenia may be achievable through a rational combination of drugs already registered, namely GLP-1 analogs. Current data converge towards adjunctive treatment with GLP-1 analogs as a potentially new avenue in the prevention and treatment of schizophrenia patients with antipsychotic-induced weight gain. Clinical research to support this idea is highly warranted.

\section{Abbreviations}

BMI: body mass index; GLP-1: Glucagon-like peptide-1; NAFLD: Non-alcoholic fatty liver disease; SGAs: second generation antipsychotics

\section{Authors' contributions}

BHE and FKK conceived of the paper and performed the literature search. BHE drafted the manuscript, which was then critically revised by each of the authors. Specifically, FKK evaluated the endocrinological studies; ER evaluated studies on magnetic resonance imaging and the implications for structural and functional brain changes; BF evaluated studies on cognition and the implications for potential cognitive improvement; and PLI, HL and BG evaluated the implications for metabolic disturbances in psychiatry. All authors read and approved the final manuscript.

\section{Competing interests}

BHE has received lecture fees from Eli Lilly and Company (producer of Byetta ${ }^{\mathbb{B}_{\circledast}}$ and Bydureon ${ }^{\mathbb{B}_{\oplus}}$ ), and is on the Eli Lilly Danmark A/S Advisory Board. FKK has received lecture fees from Novo Nordisk A/S (producer of Victoza ${ }^{\mathbb{\oplus}}$ ) and Eli Lilly and Company and on Eli Lilly Danmark A/S Advisory Board. The other authors declare that they have no competing interests.

\section{Acknowledgements}

Drs BHE and PLI have received generous funding from the Faculty of Health and Medical Sciences, University of Copenhagen and the Mental Health Services, Capital Region of Denmark. The Center for Clinical Intervention and Neuropsychiatric Schizophrenia Research, CINS is funded by a Lundbeck Foundation grant.

The decision to submit the manuscript for publication was undertaken solely by the authors and was made independently of funding sources.

\footnotetext{
Author details

${ }^{1}$ Center for Neuropsychiatric Schizophrenia Research, CNSR and Center for Clinical Intervention and Neuropsychiatric Schizophrenia Research, CINS, Psychiatric Center Glostrup, University of Copenhagen, DK-2600 Glostrup, Denmark. ${ }^{2}$ Diabetes Research Division, Department of Internal Medicine F, Gentofte Hospital, University of Copenhagen, DK-2900 Hellerup, Denmark. ${ }^{3}$ Functional Imaging Unit, FIUnit, Glostrup Hospital, University of Copenhagen, DK-2600 Glostrup, Denmark.
}

Received: 28 March 2012 Accepted: 15 August 2012

Published: 15 August 2012

\section{References}

1. McGrath J, Saha S, Chant D, Welham J: Schizophrenia: a concise overview of incidence, prevalence, and mortality. Epidemiol Rev 2008, 30:67-76.

2. Newcomer JW, Hennekens CH: Severe mental illness and risk of cardiovascular disease. JAMA 2007, 298:1794-1796.

3. Kolotkin RL, Corey-Lisle PK, Crosby RD, Swanson JM, Tuomari AV, L'italien GJ, Mitchell JE: Impact of obesity on health-related quality of life in schizophrenia and bipolar disorder. Obesity (Silver Spring) 2008, 16:749-754.

4. Due P, Heitmann BL, Sorensen TI: Prevalence of obesity in Denmark. Obes Rev 2007, 8:187-189.

5. Neovius M, Janson A, Rossner S: Prevalence of obesity in Sweden. Obes Rev 2006, 7:1-3.

6. Belanger-Ducharme F, Tremblay A: Prevalence of obesity in Canada. Obes Rev 2005, 6:183-186.

7. Baskin ML, Ard J, Franklin F, Allison DB: Prevalence of obesity in the United States. Obes Rev 2005, 6:5-7.

8. Hoang U, Stewart R, Goldacre MJ: Mortality after hospital discharge for people with schizophrenia or bipolar disorder: retrospective study of linked English hospital episode statistics, 1999-2006. BMJ 2011, 343: d5422.

9. Herrera BM, Lindgren CM: The genetics of obesity. Curr Diab Rep 2010, 10:498-505.

10. Hansen T, Ingason A, Djurovic S, Melle I, Fenger M, Gustafsson O, Jakobsen KD, Rasmussen HB, Tosato S, Rietschel M, Frank J, Owen M, Bonetto C, Suvisaari J, Thygesen JH, Pétursson H, Lönnqvist J, Sigurdsson E, Giegling I, Craddock N, O'Donovan MC, Ruggeri M, Cichon S, Ophoff RA, Pietiläinen O, Peltonen L, Nöthen MM, Rujescu D, St Clair D, Collier DA Andreassen OA, Werge T: At-risk variant in TCF7L2 for type II diabetes increases risk of schizophrenia. Biol Psychiatry 2011, 70:59-63.

11. Mukundan A, Faulkner G, Cohn T, Remington G: Antipsychotic switching for people with schizophrenia who have neuroleptic-induced weight or metabolic problems. Cochrane Database Syst Rev 2010, CD006629.

12. Tandon R, Nasrallah HA, Keshavan M: Antipsychotics, mortality and schizophrenia: What are the facts? Schizophr Res 2011, 133:262-263.

13. Rummel-Kluge C, Komossa K, Schwarz S, Hunger H, Schmid F, Lobos CA, Kissling W, Davis JM, Leucht S: Head-to-head comparisons of metabolic side effects of second generation antipsychotics in the treatment of schizophrenia: a systematic review and meta-analysis. Schizophr Res 2010, 123:225-233.

14. Allison DB, Mentore IL, Heo M, Chandler LP, Cappelleri JC, Infante MC, Weiden PJ: Antipsychotic-induced weight gain: a comprehensive research synthesis. Am J Psychiatry 1999, 156:1686-1696.

15. Lindenmayer JP, Czobor P, Volavka J, Citrome L, Sheitman B, McEvoy JP, Cooper TB, Chakos M, Lieberman JA: Changes in glucose and cholesterol levels in patients with schizophrenia treated with typical or atypical antipsychotics. Am J Psychiatry 2003, 160:290-296.

16. Fuller BE, Rodriguez VL, Linke A, Sikirica M, Dirani R, Hauser P: Prevalence of liver disease in veterans with bipolar disorder or schizophrenia. Gen Hosp Psychiatry 2011, 33:232-237.

17. Alberti KG, Eckel RH, Grundy SM, Zimmet PZ, Cleeman Jl, Donato KA, Fruchart JC, James WP, Loria CM, Smith SC Jr, International Diabetes Federation Task Force on Epidemiology and Prevention; Hational Heart, and Blood Institute; American Heart Association; World Heart Federation; International Atherosclerosis Society; International Association for the Study of Obesity: Harmonizing the metabolic syndrome: a joint interim statement of the International Diabetes Federation Task Force on Epidemiology and Prevention; National Heart, Lung, and Blood Institute; American Heart Association; World Heart Federation; International Atherosclerosis Society; and International Association for the Study of Obesity. Circulation 2009, 120:1640-1645.

18. Sikorski C, Luppa M, Kaiser M, Glaesmer H, Schomerus G, König HH, RiedelHeller SG: The stigma of obesity in the general public and its implications for public health - a systematic review. BMC Public Health 2011, 11:661.

19. Dixon JB: The effect of obesity on health outcomes. Mol Cell Endocrinol 2010, 316:104-108 
20. WHO: The World Health Report : 2001 : Mental health : new understanding, new hope 2001

21. Withrow D, Alter DA: The economic burden of obesity worldwide: a systematic review of the direct costs of obesity. Obes Rev 2011, 12:131-141.

22. Wang YC, McPherson K, Marsh T, Gortmaker SL, Brown M: Health and economic burden of the projected obesity trends in the USA and the UK. Lancet 2011, 378:815-825.

23. Hulshoff Pol HE, Kahn RS: What happens after the first episode? A review of progressive brain changes in chronically ill patients with schizophrenia. Schizophr Bull 2008, 34:354-366.

24. Jagust $\mathrm{W}$ : What can imaging reveal about obesity and the brain? Curr Alzheimer Res 2007, 4:135-139.

25. Gabriele JM, Dubbert PM, Reeves RR: Efficacy of behavioural interventions in managing atypical antipsychotic weight gain. Obes Rev 2009, 10:442-455.

26. Maayan L, Vakhrusheva J, Correll CU: Effectiveness of medications used to attenuate antipsychotic-related weight gain and metabolic abnormalities: a systematic review and meta-analysis. Neuropsychopharmacology 2010, 35:1520-1530.

27. Mitri J, Hamdy O: Diabetes medications and body weight. Expert Opin Drug Saf 2009, 8:573-584

28. Evans $S$, Newton R, Higgins S: Nutritional intervention to prevent weight gain in patients commenced on olanzapine: a randomized controlled trial. Aust N Z J Psychiatry 2005, 39:479-486.

29. Centorrino F, Wurtman JJ, Duca KA, Fellman VH, Fogarty KV, Berry JM, Guay DM, Romeling M, Kidwell J, Cincotta SL, Baldessarini RJ: Weight loss in overweight patients maintained on atypical antipsychotic agents. Int J Obes (Lond) 2006, 30:1011-1016.

30. Wu RR, Zhao JP, Jin H, Shao P, Fang MS, Guo XF, He YQ, Liu YJ, Chen JD, Li LH: Lifestyle intervention and metformin for treatment of antipsychotic-induced weight gain: a randomized controlled trial. JAMA 2008, 299:185-193

31. Ben-David K, Rossidis G: Bariatric surgery: indications, safety and efficacy. Curr Pharm Des 2011, 17:1209-1217.

32. Gibson CD, Carnell S, Ochner CN, Geliebter A: Neuroimaging, gut peptides and obesity: novel studies of the neurobiology of appetite. I Neuroendocrinol 2010, 22:833-845.

33. Neary MT, Batterham RL: Gut hormones: implications for the treatment of obesity. Pharmacol Ther 2009, 124:44-56.

34. Holst JJ: The physiology of glucagon-like peptide 1. Physiol Rev 2007, 87:1409-1439

35. Vilsboll T, Christensen M, Junker AE, Knop FK, Gluud LL: Effects of glucagon-like peptide-1 receptor agonists on weight loss: systematic review and meta-analyses of randomised controlled trials. BMJ 2012, 344: d7771.

36. Astrup A, Carraro R, Finer N, Harper A, Kunesova M, Lean ME, Niskanen L, Rasmussen MF, Rissanen A, Rössner S, Savolainen MJ, Van Gaal L: Safety, tolerability and sustained weight loss over 2 years with the once-daily human GLP-1 analog, liraglutide. Int J Obes (Lond) 2012, 36:890.

37. Sharma S, Mells JE, Fu PP, Saxena NK, Anania FA: GLP-1 analogs reduce hepatocyte steatosis and improve survival by enhancing the unfolded protein response and promoting macroautophagy. PLoS One 2011, 6: e25269.

38. Mells JE, Fu PP, Sharma S, Olson DE, Cheng L, Handy JA, Saxena NK, Sorescu D, Anania FA: GLP-1 analog, liraglutide ameliorates hepatic steatosis and cardiac hypertrophy in C57BL/6J mice fed a Western diet. Am J Physiol Gastrointest Liver Physiol 2012, 302:G225-235.

39. Lykkegaard K, Larsen PJ, Vrang N, Bock C, Bock T, Knudsen LB: The oncedaily human GLP-1 analog, liraglutide, reduces olanzapine-induced weight gain and glucose intolerance. Schizophr Res 2008, 103:94-103.

40. Amori RE, Lau J, Pittas AG: Efficacy and safety of incretin therapy in type 2 diabetes: systematic review and meta-analysis. JAMA 2007, 298:194-206.

41. During MJ, Cao L, Zuzga DS, Francis JS, Fitzsimons HL, Jiao X, Bland RJ, Klugmann M, Banks WA, Drucker DJ, Haile CN: Glucagon-like peptide-1 receptor is involved in learning and neuroprotection. Nat Med 2003, 9:1173-1179.

42. Holst JJ, Burcelin R, Nathanson E: Neuroprotective properties of GLP-1: theoretical and practical applications. Curr Med Res Opin 2011, 27:547-558.

43. McClean PL, Parthsarathy V, Faivre E, Holscher C: The diabetes drug liraglutide prevents degenerative processes in a mouse model of Alzheimer's disease. J Neurosci 2011, 31:6587-6594.
44. McClean PL, Gault VA, Harriott P, Holscher C: Glucagon-like peptide-1 analogues enhance synaptic plasticity in the brain: a link between diabetes and Alzheimer's disease. Eur J Pharmacol 2010, 630:158-162.

45. Bertilsson G, Patrone C, Zachrisson O, Andersson A, Dannaeus K, Heidrich J, Kortesmaa J, Mercer A, Nielsen E, Rönnholm H, Wikström L: Peptide hormone exendin- 4 stimulates subventricular zone neurogenesis in the adult rodent brain and induces recovery in an animal model of Parkinson's disease. J Neurosci Res 2008, 86:326-338.

46. Martin B, Golden E, Carlson OD, Pistell P, Zhou J, Kim W, Frank BP, Thomas S, Chadwick WA, Greig NH, Bates GP, Sathasivam K, Bernier M, Maudsley S, Mattson MP, Egan JM: Exendin-4 improves glycemic control, ameliorates brain and pancreatic pathologies, and extends survival in a mouse model of Huntington's disease. Diabetes 2009, 58:318-328.

47. Shenton ME, Kikinis R, Jolesz FA, Pollak SD, LeMay M, Wible CG, Hokama H, Martin J, Metcalf D, Coleman M: Abnormalities of the left temporal lobe and thought disorder in schizophrenia. A quantitative magnetic resonance imaging study. N Engl J Med 1992, 327:604-612.

48. Vita A, De Peri L, Silenzi C, Dieci M: Brain morphology in first-episode schizophrenia: a meta-analysis of quantitative magnetic resonance imaging studies. Schizophr Res 2006, 82:75-88.

49. Steen RG, Mull C, McClure R, Hamer RM, Lieberman JA: Brain volume in first-episode schizophrenia: systematic review and meta-analysis of magnetic resonance imaging studies. Br J Psychiatry 2006, 188:510-518.

50. Ebdrup BH, Glenthoj B, Rasmussen H, Aggernaes B, Langkilde AR, Paulson OB, Lublin H, Skimminge A, Baaré W: Hippocampal and caudate volume reductions in antipsychotic-naive first-episode schizophrenia. J Psychiatry Neurosci 2010, 35:95-104.

51. Buchanan RW, Kreyenbuhl J, Kelly DL, Noel JM, Boggs DL, Fischer BA, Himelhoch S, Fang B, Peterson E, Aquino PR, Keller W, Schizophrenia Patient Outcomes Research Team (PORT): The 2009 schizophrenia PORT psychopharmacological treatment recommendations and summary statements. Schizophr Bull 2010, 36:71-93.

52. Gunstad J, Paul RH, Cohen RA, Tate DF, Spitznagel MB, Grieve S, Gordon E: Relationship between body mass index and brain volume in healthy adults. Int J Neurosci 2008, 118:1582-1593.

53. Taki Y, Kinomura S, Sato K, Inoue K, Goto R, Okada K, Uchida S, Kawashima R, Fukuda H: Relationship between body mass index and gray matter volume in 1,428 healthy individuals. Obesity (Silver Spring) 2008, 16:119-124.

54. Pannacciulli N, Del Parigi A, Chen K, Le DS, Reiman EM, Tataranni PA: Brain abnormalities in human obesity: a voxel-based morphometric study. Neuroimage 2006, 31:1419-1425.

55. Gazdzinski S, Kornak J, Weiner MW, Meyerhoff DJ: Body mass index and magnetic resonance markers of brain integrity in adults. Ann Neurol 2008, 63:652-657.

56. Gazdzinski S, Millin R, Kaiser LG, Durazzo TC, Mueller SG, Weiner MW, Meyerhoff $D J$ : BMI and neuronal integrity in healthy, cognitively normal elderly: a proton magnetic resonance spectroscopy study. Obesity (Silver Spring) 2010, 18:743-748.

57. Willeumier KC, Taylor DV, Amen DG: Elevated BMI is associated with decreased blood flow in the prefrontal cortex using SPECT imaging in healthy adults. Obesity (Silver Spring) 2011, 19:1095-1097.

58. Pinkham A, Loughead J, Ruparel K, Wu WC, Overton E, Gur R, Gur R: Resting quantitative cerebral blood flow in schizophrenia measured by pulsed arterial spin labeling perfusion MRI. Psychiatry Res 2011, , 194: 64-72.

59. Stanek KM, Grieve SM, Brickman AM, Korgaonkar MS, Paul RH, Cohen RA, Gunstad JJ: Obesity is associated with reduced white matter integrity in otherwise healthy adults. Obesity (Silver Spring) 2011, 19:500-504.

60. Kyriakopoulos M, Bargiotas T, Barker GJ, Frangou S: Diffusion tensor imaging in schizophrenia. Eur Psychiatry 2008, 23:255-273.

61. Maayan L, Hoogendoorn C, Sweat V, Convit A: Disinhibited eating in obese adolescents is associated with orbitofrontal volume reductions and executive dysfunction. Obesity (Silver Spring) 2011, 19:1382-1387.

62. Dazzan P, Soulsby B, Mechelli A, Wood SJ, Velakoulis D, Phillips $L$, Yung AR, Chitnis X, Lin A, Murray RM, McGorry PD, McGuire PK, Pantelis C: Volumetric abnormalities predating the onset of schizophrenia and affective psychoses: an MRI study in subjects at ultrahigh risk of psychosis. Schizophr Bull 2011.

63. Peters A, Bosy-Westphal A, Kubera B, Langemann D, Goele K, Later W, Heller M, Hubold C, Müller MJ: Why doesn't the brain lose weight, when obese people diet? Obes Facts 2011, 4:151-157. 
64. Siervo M, Arnold R, Wells JC, Tagliabue A, Colantuoni A, Albanese E, Brayne C, Stephan BC: Intentional weight loss in overweight and obese individuals and cognitive function: a systematic review and metaanalysis. Obes Rev 2011, 12:968-983.

65. DelParigi A, Pannacciulli N, Le DN, Tataranni PA: In pursuit of neural risk factors for weight gain in humans. Neurobiol Aging 2005, 26(Suppl 1):50-55.

66. Benetti S, Mechelli A, Picchioni M, Broome M, Williams S, McGuire P: Functional integration between the posterior hippocampus and prefrontal cortex is impaired in both first episode schizophrenia and the at risk mental state. Brain 2009, 132:2426-2436.

67. Burger KS, Stice E: Variability in reward responsivity and obesity: evidence from brain imaging studies. Curr Drug Abuse Rev 2011, 4:182-189.

68. Nielsen MO, Rostrup E, Wulff S, Bak N, Lublin H, Kapur S, Glenthøj B: Alterations of the brain reward system in antipsychotic naive schizophrenia patients. Biol Psychiatry 2012, 71:898-905.

69. Brinkworth GD, Buckley JD, Noakes M, Clifton PM, Wilson CJ: Long-term effects of a very low-carbohydrate diet and a low-fat diet on mood and cognitive function. Arch Intern Med 2009, 169:1873-1880

70. Exenatide for the Treatment of Weight Gain Associated With Olanzapine in Obese Adults. , ClinicalTrials.gov http://clinicaltrials.gov/ct2/show/ NCT00845507.

71. De Hert M, Detraux J, van Winkel R, Yu W, Correll CU: Metabolic and cardiovascular adverse effects associated with antipsychotic drugs. Nat Rev Endocrinol 2011, 18:114-126.

72. Shyangdan DS, Royle P, Clar C, Sharma P, Waugh N, Snaith A: Glucagonlike peptide analogues for type 2 diabetes mellitus. Cochrane Database Syst Rev 2011, CD006423.

73. Grant P, Lipscomb D, Quin J: Psychological and quality of life changes in patients using GLP-1 analogues. J Diabetes Complications 2011, 25:244-246.

Pre-publication history

The pre-publication history for this paper can be accessed here: http://www.biomedcentral.com/1741-7015/10/92/prepub

doi:10.1186/1741-7015-10-92

Cite this article as: Ebdrup et al:: Glucagon-like peptide-1 analogs against antipsychotic-induced weight gain: potential physiological benefits. BMC Medicine 2012 10:92.

\section{Submit your next manuscript to BioMed Central and take full advantage of:}

- Convenient online submission

- Thorough peer review

- No space constraints or color figure charges

- Immediate publication on acceptance

- Inclusion in PubMed, CAS, Scopus and Google Scholar

- Research which is freely available for redistribution

Submit your manuscript at www.biomedcentral.com/submit
Biomed Central 